\title{
Effect of light and heat on bleaching action of hydrogen peroxide
}

\author{
Efeito da luz e calor na ação clareadora do peróxido de hidrogênio \\ Efecto de la luz y el calor sobre la acción aclaradora del peróxido de hidrógeno
}

Received: 09/20/2021 | Reviewed: 09/30/2021 | Accept: 09/30/2021| Published: 10/22/2021

\author{
May Anny Alves Fraga \\ ORCID: https://orcid.org/0000-0002-9323-0862 \\ University of Campinas, Brazil \\ E-mail: mayannyfraga@ hotmail.com \\ João Pedro Castello Marcatto \\ ORCID: https://orcid.org/0000-0003-1892-5282 \\ University of Campinas, Brazil \\ E-mail: jpmarcatto@icloud.com \\ Talita Malini Carletti \\ ORCID: https://orcid.org/0000-0002-1549-2621 \\ University of Campinas, Brazil \\ E-mail: talitacarletti@gmail.com \\ Lourenço Correr Sobrinho \\ ORCID: https://orcid.org/0000-0002-2009-7407 \\ University of Campinas, Brazil \\ E-mail: sobrinho@fop.unicamp.br \\ Américo Bortolazzo Correr \\ ORCID: https://orcid.org/0000-0002-3306-7055 \\ University of Campinas, Brazil \\ E-mail: acorrer@unicamp.br
}

\begin{abstract}
This study aimed to verify the effect of light and heat on bleaching action of $40 \%$ hydrogen peroxide (Opalescence Boost PF Ultradent, BR). Thirty-three bovine incisors were submitted to in-office dental bleaching and divided into three groups ( $\mathrm{n}=11$ ): CO group - control, no light or heat; CA group - heat with a hairdryer; LC group - light and heat with a photoactivation device. For this, a gingival barrier (OpalDam - Ultradent, SP, BR) isolated a circular area around the flatter region of the crown. Afterwards, the bleaching gel was applied for 15 minutes and repeated twice, totaling 45 minutes of application. For the CA and LC groups, the heat source was maintained during the application of the bleaching gel. Temperature was standardized in $5^{\circ} \mathrm{C}$ for both groups and monitored using a thermocouple inserted into the pulp chamber. The color measurement was performed before and after bleaching using a spectrophotometer. The inner margin of the isolated area of each dental crown was equivalent to the tip of the spectrophotometer $(4 \mathrm{~mm})$. Color change was verified by CIEDE2000 system $(\Delta E 00)$. One way ANOVA and Tukey's test were used to analyze data (p-values set to $5 \%$ ). The values of $\Delta \mathrm{E} 00$ were equal for LC $(2,66 \pm 0,29)$ and CA $(2,44 \pm 0,88)$, and both were higher than CO $(1,31 \pm 0,37)$. Therefore, light does not play a fundamental role for in-office dental bleaching. Same dental bleaching outcomes are obtained using different heat sources.
\end{abstract}

Keywords: Tooth Bleaching; Carbamide Peroxide; Light; Temperature.

\section{Resumo}

O objetivo neste trabalho foi verificar o efeito da luz e do calor na ação clareadora do peróxido de hidrogênio $40 \%$ (Opalescence Boost PF - Ultradent, BR). Trinta e três incisivos bovinos foram submetidos ao clareamento de consultório e divididos em três grupos: Grupo CO - controle, sem luz e sem calor; Grupo CA - calor do secador de cabelo; Grupo LC - luz e calor com fotoativador. Para isso, uma barreira gingival (OpalDam - Ultradent, SP, BR) foi utilizada para isolar uma área circular ao redor da região mais plana da coroa. Após, o gel clareador foi aplicado por 15 minutos e repetido duas vezes, totalizando 45 minutos de aplicação. Para os grupos CA e LC, a fonte de calor foi mantida durante a aplicação do gel clareador. A temperatura foi padronizada em $5^{\circ} \mathrm{C}$ para ambos os grupos e monitorada por meio de um termopar inserido na câmara pulpar. A cor das amostras foi aferida antes e após o procedimento clareador, por meio de um espectrofotômetro. A margem interna da área isolada de cada coroa dental era equivalente à ponta do espectofotometro (4 mm). A alteração de cor foi verificada por meio do sistema CIEDE2000 ( $\Delta \mathrm{E} 00)$. Os resultados foram estatisticamente analisados por ANOVA 1-fator e teste post-hoc de Tukey (nível de significância de 5\%). Os valores de $\Delta \mathrm{E} 00$ de LC $(2,66 \pm 0,29)$ e CA $(2,44 \pm 0,88)$ foram maiores que CO $(1,31 \pm 0,37)$. Portanto, conclui-se que a luz não desempenha um papel fundamental no processo de clareamento de consultório, sendo possível obter os mesmos resultados somente com fonte de calor.

Palavras-chave: Clareamento dental; Peróxido de hidrogênio; Luz; Temperatura.

\section{Resumen}

Este estudio objetivó verificar el efecto de la luz y el calor sobre la acción blanqueadora del peróxido de hidrógeno al $40 \%$ (Opalescence Boost PF - Ultradent, BR). Treinta y tres incisivos bovinos fueron sometidos a blanqueamiento dental en el consultorio y se dividieron en tres grupos $(n=11)$ : grupo de $\mathrm{CO}$ - control, sin luz ni calor; Grupo CA - calentar con secador de 
pelo; Grupo LC: luz y calor con un dispositivo de fotoactivación. Una barrera gingival (OpalDam - Ultradent, SP, BR) fue aplicada para aislar un área circular alrededor de la región más plana de la corona. Posteriormente se aplicó el gel blanqueador durante 15 minutos y se repitió dos veces, totalizando 45 minutos de aplicación. Para los grupos CA y LC, la fuente de calor se mantuvo durante la aplicación del gel blanqueador. La temperatura se estandarizó em $5^{\circ} \mathrm{C}$ para ambos grupos y se controló mediante un termopar insertado en la cámara pulpar. La medición del color se realizó antes y después del blanqueo usando un espectrofotómetro. El margen interno del área aislada de cada corona dental fue equivalente a la punta del espectrofotómetro (4 $\mathrm{mm})$. El cambio de color fue verificado por el sistema CIEDE2000 ( $\Delta$ E00). Se utilizaron ANOVA de una forma y la prueba de Tukey para analizar los datos (valores de p establecidos en $5 \%$ ). Los valores de $\triangle \mathrm{E} 00$ fueron iguales para LC $(2,66 \pm 0,29)$ y CA $(2,44 \pm 0,88)$, y ambos fueron superiores a CO $(1,31 \pm 0,37)$. Por tanto, la luz no juega un papel fundamental para el blanqueamiento dental en consultorio. Se obtienen los mismos resultados de blanqueamiento dental utilizando diferentes fuentes de calor.

Palabras clave: Aclaramiento Dental; Peróxido Hidrógeno; Luz; Temperatura.

\section{Introduction}

Aesthetics is a science comprising beauty and artistic forms, harmony of shapes, colors, and customs (Michaelis, 1998). In Dentistry, tooth color is a relevant characteristic for an aesthetically pleasing smile, but extrinsic or intrinsic pigments can modify it. Extrinsic stains are usually removed through routine prophylactic procedures (Viscio et al., 2000; NakoniecznaRudnicka et al., 2015); however, when some spots do not respond to this type of treatment, bleaching agents are good alternatives to remove spots and make a smile lighter (Alqahtani, 2014; Torres et al., 2021).

Dental bleaching began around 1870 when attempts to whiten vital and non-vital teeth were made using oxalic acid. In 1937, the use of hydrogen peroxide associated with ethyl ether was also reported (Ames, 1973). Over the years, bleaching agents have evolved, allowing bleaching techniques to reach biological safety for patients and expand protocols of home or inoffice techniques (Alqahtani, 2014).

In general, at-home dental bleaching procedures uses carbamide peroxide or low concentration hydrogen peroxide gels. These materials release oxygen free radicals that penetrate the organic matrix of enamel and dentin and oxidize pigmented macromolecules into smaller molecules capable of reflecting light (Lima et al., 2019). Carbamide peroxide acts more slowly, decomposing into urea and hydrogen peroxide. For this reason, carbamide peroxide is preferred for at-home dental bleaching as its slower decomposition reduces tooth sensitivity (Lima et al., 2019).

Although at-home technique is frequently performed, patients have difficulties adapting to the bleaching tray, whose protocol requires daily use every night for two to three weeks (Luque-Martinez et., 2016). Bleaching gels concentrations range from 10 to $22 \%$ of carbamide peroxide or 1.5 to $10 \%$ of hydrogen peroxide. Low concentrations of bleaching agents require more time and patient cooperation (Sulieman, 2004; Torres et al., 2021). In contrast, fast results are obtained in-office once high concentrations of hydrogen peroxide (15 to 40\%) or carbamide peroxide (22 to 37\%) are applied, with or without light (Haywood, 2000; Ontiveros, 2011). In contrast, fast results are obtained in-office once high concentrations of hydrogen peroxide (15 to 40\%) or carbamide peroxide (22 to 37\%) are applied, with or without light (Haywood, 2000; Ontiveros, 2011). Thus, hydrogen peroxide for in-office dental bleaching gains space in the dental market once patient collaboration is not required.

In 1911, dental bleaching protocol was improved associating hydrogen peroxide and light (Fisher, 1911). Since then, different light sources have been employed, such as lasers, LED (Light-Emitting Diode), and halogen lamps, enhancing bleaching gels efficiency through hydrogen peroxide or carbamide peroxide catalysis (Buchalla et al., 2007). In contrast, doubts about light potential to produce bleaching effects still exist (Maran et al., 2019). It is supposed that pigments are removed through the wavelength (Alshammery, 2019) or the catalyst reaction of bleaching gel with heat. Regarding the exothermic reaction of hydrogen peroxide decomposition $(23.44 \mathrm{kcal} / \mathrm{mol})$, temperature increases with light, accelerating dental bleaching gel's decomposition rate (Davidi et al., 2008). Nonetheless, it is not well established whether light or heat is responsible for increased bleaching action of hydrogen peroxide. Thus, this study aimed to evaluate different heat sources on 
hydrogen peroxide dental bleaching agents. The null hypothesis is that no differences exist among bleaching protocols when light or heat sources are applied.

\section{Methodology}

\subsection{Experimental Design}

This study assessed light and heat effect on a 40\% hydrogen peroxide dental bleaching agent (Opalescence Boost PF - Ultradent, Brazil). According to the heat protocol, thirty-three bovine incisors were divided into three groups: CO group control, no light or heat; CA group - heat with a hairdryer; LC group - light and heat with a photoactivation device (Figure 1).

Figure 1. Experimental design.

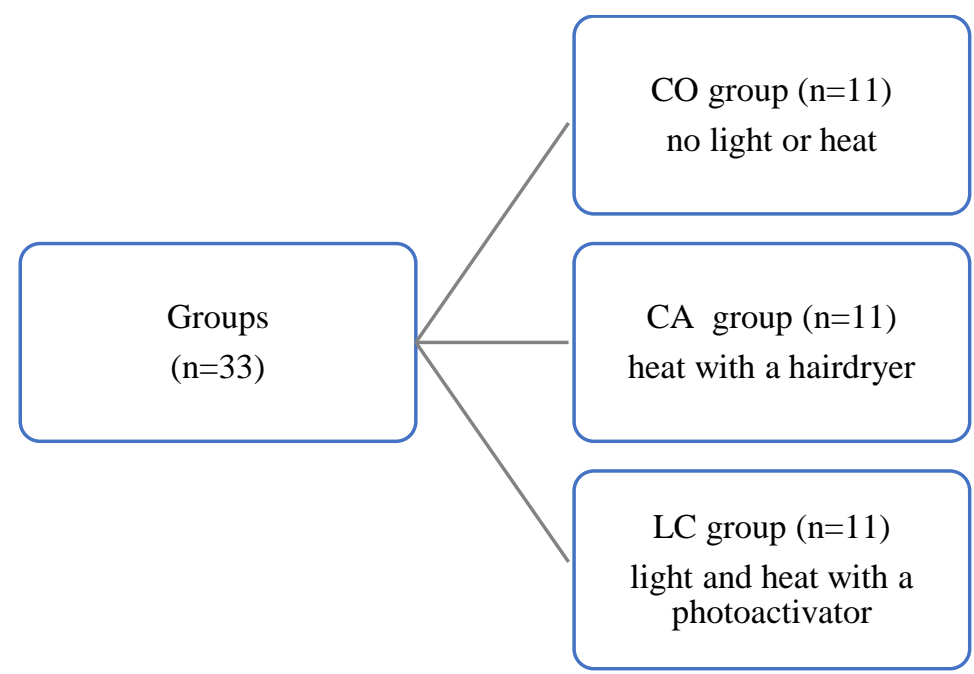

Source: Personal archives (2021).

\subsection{Sample selection}

Bovines' incisors were cleaned and stored in freezers for up to three months after extraction. Magnifying glasses were used to exclude teeth with deformities, anatomical variation, and cracks, impairing color analysis. Only teeth sound and free from surface defects were included in the study.

\subsection{Pilot study}

A pilot study was performed with three samples for each group to determine the distance from light source application, so that heat quantity was similar for all groups. A photoactivation device (VALO Cordless, 385-515nm, Ultradent, $\mathrm{SP}, \mathrm{BR}$ ) was placed $1 \mathrm{~cm}$ from the tooth in the LC group. A thermoelectric couple type $\mathrm{K}$ connected to a digital thermometer (TH1300, Instrutherm, São Paulo, SP, Brazil) with $0,1^{\circ} \mathrm{C}$ precision determined heat incidence over teeth during light activation (Figures 2 and 3). Temperature was standardized in $5^{\circ} \mathrm{C}$ for both groups and monitored using a thermocouple inserted into the pulp chamber. The same procedure was performed with the hairdryer, perpendicularly placed $45 \mathrm{~cm}$ distant from the tooth (Figure 4), slightly positioned to the left of the sample, avoiding the spread of bleaching gel, until obtaining the same 
temperature provided by photoactivation device. This distance provided a temperature similar to the photoactivation device, which increased by $5^{\circ} \mathrm{C}$ after $15 \mathrm{~min}$.

Figure 2. Digital thermometer for initial temperature measurement without heat.

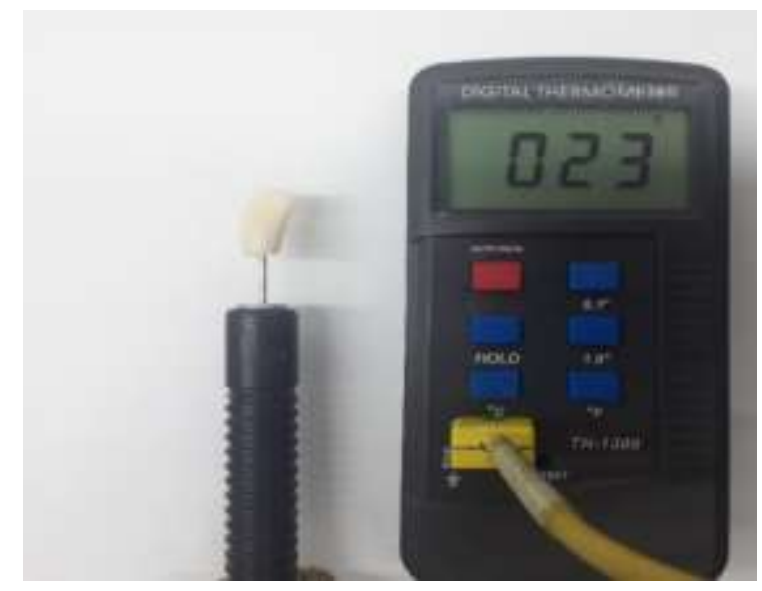

Source: Personal archives (2021).

Figure 3. Digital thermometer for initial temperature measurement with heat.

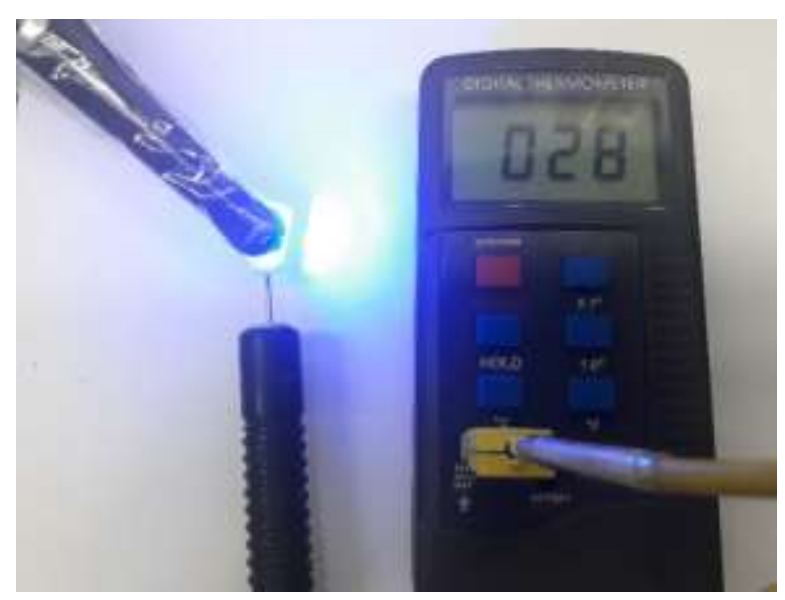

Source: Personal archives (2021).

The pilot study assigned sampling calculation using the G-power software considering $\alpha=0.05$ and $\beta=0.2,80 \%$ power test. In total, 33 samples were obtained ( $n=11$ /group). 
Figure 4. Distance from the air dryer to the sample $(45 \mathrm{~cm})$.

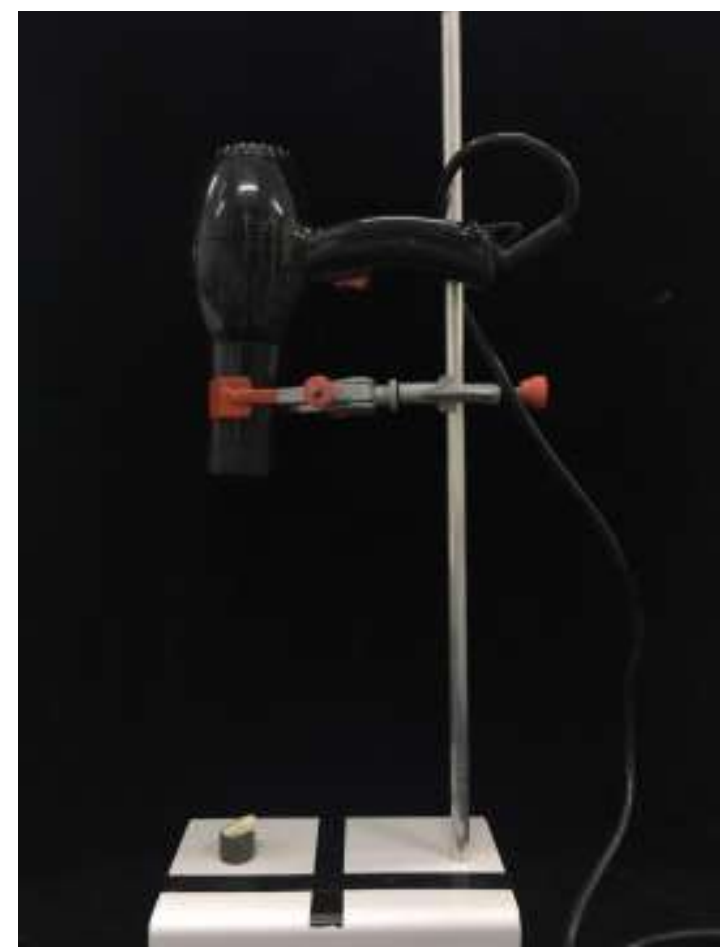

Source: Personal archives (2021).

\subsection{Sample preparation and bleaching procedures}

Teeth had their roots removed and were cleaned with a Robinson brush, pumice stone, and water. A gingival barrier (OpalDam - Ultradent, SP, BR) isolated a circular-shaped area in the flattest region of the crown before dental bleaching gel application. The inner margin diameter of the area was equivalent to the diameter of spectrophotometer tip ( $4 \mathrm{~mm})$, ensuring that readings were carried out in the same region. A $40 \%$ hydrogen peroxide bleaching gel layer, 0.5 to $1.0 \mathrm{~mm}$ thick (Opalescence Boost PF - Ultradent, BR), was applied on tooth surface for 15 minutes and repeated twice, totalizing a 45minute application, according to manufacturer's instructions. In groups CA and LC, heat source was maintained throughout application of bleaching gel.

\subsection{Color analysis}

Color analyses were made before and after bleaching procedure in a controlled lightbox with white background (D65 lightbox GTI MiniMatcher, Gti Graphic Technology). For this, VITA Easyshade spectrophotometer (VITA Zahnfabrik H. Rauter GmbH \& Co.KG, Bad Sackingen, Germany) (Figure 5) was used to obtain L*, $\mathrm{C}^{*}$ and $\mathrm{H}^{*}$ coordinates, determining color change according to CIEDE2000 formula (Liu et al., 2013):

$$
\Delta \mathrm{E} 00=[(\Delta \mathrm{L} / \mathrm{KL} . \mathrm{SL}) 2+(\Delta \mathrm{C} / \mathrm{KC} . \mathrm{SC}) 2+(\Delta \mathrm{H} / \mathrm{KH} . \mathrm{SH}) 2+\mathrm{RT} .(\Delta \mathrm{C} / \mathrm{KC} . \mathrm{SC}) .(\Delta \mathrm{H} / \mathrm{KH} . \mathrm{SH})] 0.5
$$

where $\Delta \mathrm{L}, \Delta \mathrm{C}$ e $\Delta \mathrm{H}$ represent differences between lightning, chroma, and hue initial and final values. $\mathrm{RT}$ explains the interaction between chroma and hue differences in blue region. $\mathrm{KL}, \mathrm{KC}$, and $\mathrm{KH}$ are correction terms for experimental conditions set to a value of 1 (Sharma et al., 2005). The equipment was calibrated for every 10 samples, reading a sample provided by the manufacturer. A single trained evaluator performed all measurements. 
Figure 5. VITA Easyshade spectrophotometer.

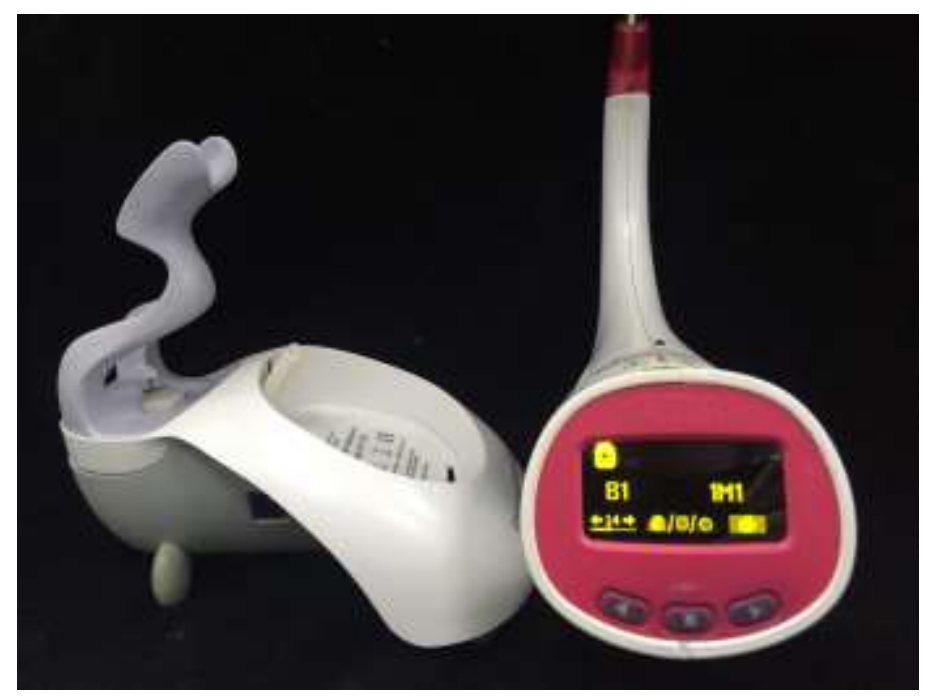

Source: Personal archives (2021).

\subsection{Statistical analysis}

After the Shapiro-Wilk test confirmed data normality, one-way ANOVA and Tukey's post-hoc tests were applied to compare groups. The significance level was set to 5\%. All statistical tests were performed using SPSS 21 software (IBM Corp. Released 2012. IBM SPSS Statistics for Windows, Version 21.0. Armonk, NY: IBM Corp.).

\section{Results and Discussion}

Table 1 shows mean and standard deviation of $\Delta \mathrm{E} 00$ values for each group. Heat lightened tooth color $(\mathrm{F}=12.44$ and $\mathrm{p}<0.001)$. However, color did not change between different heat sources $(\Delta \mathrm{E} 00=2.44(\mathrm{CA})$ and $\Delta \mathrm{E} 00=2.66(\mathrm{CL})$; $\mathrm{p}<0.05$ ), meaning no noticeable clinical differences.

Table 1. Mean and standard deviation of $\Delta \mathrm{E} 00$ values.

\begin{tabular}{lccc}
\hline Groups & Mean & Standard deviation & Tukey test \\
\hline Control (CO) & 1.31 & 0.37 & $\mathrm{~B}$ \\
Hairdryer (CA) & 2.44 & 0.88 & $\mathrm{~A}$ \\
Photoactivation (CL) & 2.66 & 0.29 & $\mathrm{~A}$ \\
\hline
\end{tabular}

Different letters mean statistical differences between groups $(\mathrm{p}<0.05)$.

Source: personal archives (2021).

No differences were found between different bleaching protocols with $40 \%$ hydrogen peroxide when a light or heat source was used on dental bleaching protocol, rejecting the null hypothesis. Color change was more advantageous in groups CA and CL than CO, despite no differences have been found between heat sources. It suggests that heat may significantly increase bleaching potential, regardless of light or hot air emission. Several light sources, mainly LEDs, have activated dental bleaching by heating hydrogen peroxide, disintegrating into free radicals, and oxidizing complex organic molecules (Maran et al., 2018). In addition, raising temperature from $37^{\circ}$ to $45^{\circ}$ Celsius, in a controlled and biocompatible way, improves bleaching, reducing the application time of bleaching gel (Davidi et al., 2008). Regardless of equipment, heating bleaching gel 
is known as thermocatalysis (Ontiveros et al., 2009), expressed by the following equation: $\mathrm{H} 2 \mathrm{O} 2+211 \mathrm{~kJ} / \mathrm{mol} \rightarrow 2 \mathrm{HO}$. The reaction increases hydroxyl free radicals release from peroxide molecules, enhancing bleaching procedure and achieving fast results (Buchalla et al., 2007). The more heat, the more radicals will be released.

Despite the known thermocatalysis mechanism, using light in bleaching protocols is still not well determined since studies outcomes are ambiguous. For example, clinical studies have observed no significant scientific evidence of light source in the activation process of in-office dental bleaching (Ray et al., 2014), with no influence on color change or sensitivity, regardless of hydrogen peroxide concentration (Alshammery, 2019). The same study corroborates results from a recent systematic review showing that light sources could not positively affect dental bleaching (Maran et al., 2019). Despite this, the study points out few clinical studies for each type of light source (Maran et al., 2019). Moreover, the wide variety of protocols difficult to determine the actual effect of light as an accelerator of dental bleaching process.

Recently, violet LEDs associated with bleaching gel improved bleaching effect of hydrogen peroxide without affecting mineral structures of enamel (Kury et al., 2020). It is speculated that the short wavelength of violet light (405 $\mathrm{nm}$ ) may present a photolytic effect, breaking same absorption spectrum pigments on enamel surface (Alshammery, 2019). On the other hand, a clinical study evidenced a low capacity of violet light to promote a bleaching effect compared to $40 \%$ hydrogen peroxide (Kury et al., 2020). However, increased bleaching potential was found associating carbamide and hydrogen peroxide and LED (Kury et al. 2020), corroborating our results. In our study, groups CL and CA were similar when another heat source was used. Thus, it is likely that heat generated by LED provided a catalytic effect rather than wavelength itself.

Other studies had also found better bleaching results when LED was used in dental bleaching procedures (Ontiveros et al., 2009; Fernandes et al., 2020; Gallinari et al., 2020). Violet light can improve dental bleaching efficiency (Brugnera et al, 2019). Nonetheless, a multiwave dental LED with violet spectrum $(385-515 \mathrm{~nm})$ for photoactivation procedures was used in our study; thus, it can be hypothesized that violet light favored the highest values of color change in CL group. However, violet light contribution was slight, not differing the CA group.

Even though heat fastens bleaching effect, intrapulpal damage may occur depending on light intensity. Bleaching gels with orange pigments absorb blue light emitted by the photoactivation device and, by consequence, increase temperature of tooth surface and pulp chamber, explaining the photopotentiated mechanism of bleaching techniques using light (Loretto et al., 2013). In clinical situations, rising temperature to accelerate dental bleaching chemical reaction likely increase dental sensibility. Thus, safety bleaching procedures are performed without light sources (Aras, 2014). The amount of heat generated in the study was high, but temperature was lower than the critical pulp temperature, which can be raised to around $5.5^{\circ} \mathrm{C}$ without internal damage to pulp tissues (Zach et al, 1965). Therefore, our protocol is safe for clinical application.

Assessing only one type of light and heat sources were the limitations of this study. To avoid the bleaching gel dryness, for instance, another heat source could be chosen. In addition, longitudinal studies could assess whether heat has positive effects on dental bleaching. Despite limitations imposed by an in-vitro study, comparable results can be obtained using heat sources, not necessarily a LED, putting in doubt its real need for clinical application.

\section{Conclusions}

Light does not play a fundamental role in-office dental bleaching. Same dental bleaching outcomes are obtained using different heat sources.

\section{Acknowledgments}

Authors acknowledge the Ph.D. scholarships granted by the Coordenação de Aperfeiçoamento de Pessoal de Nível Superior - Brasil (CAPES, Finance Code 001) and PROEX n.0878/2018. 


\section{References}

Alqahtani, M. Q. (2014). Tooth-bleaching procedures and their controversial effects: A literature review. Saudi Dent J, 26(2), 33-46.

Alshammery, S. (2019). Evaluation of Light Activation on In-office Dental Bleaching: A Systematic Review. J Contemp Dent Pract, 20(11), 1355-60.

Ames, J. W. (1937). Removing Stains from Mottled Enamel. The Journal of the American Dental Association and The Dental Cosmos, $24(10)$, $1674-1677$.

Aras, W. (2014). Dental Whitening: with or without photoactivation?. Revista de Odontologia da Universidade Cidade de São Paulo. 26 , $150-154$.

Brugnera, A. P., Nammour, S., Rodrigues, J. A., Mayer-Santos, E., de Freitas, P. M., Brugnera, A., \& Zanin, F. (2020). Clinical Evaluation of In-Office Dental Bleaching Using a Violet Light-Emitted Diode. Photobiomodul Photomed Laser Surg, 38(2), 98-104.

Buchalla, W., \& Attin, T. (2007). External bleaching therapy with activation by heat, light or laser--a systematic review. Dent Mater, 23(5), 586-96.

Davidi, M. P., Hadad, A., Weiss, E. I., Domb, A., Mizrahi, B., \& Sterer, N. (2008). The effect of a mild increase in temperature on tooth bleaching. Quintessence Int, 39(9), 771-775.

Fernandes, B. M., Tanaka, M. H., De Oliveira, A. L. B. M., \& Scatolin, R. S. (2020). Color Stability of Dental Enamel Bleached with Violet LED Associated with or Without Low Concentration Peroxide Gels. Photodiagnosis Photodyn Ther, 16, 102101.

Fisher, G. (1911). The bleaching of discolored teeth with H2O2. Dent. Cosmos, 53, 246-247

Gallinari, M. O., Cintra, L. T. A., Barboza, A. C. S., da Silva, L. M. A. V., de Alcantara, S., \& Dos Santos PH. (2020). Evaluation of the color change and tooth sensitivity in treatments that associate violet LED with carbamide peroxide $10 \%$ : A randomized clinical trial of a split-mouth design. Photodiagnosis Photodyn Ther, 30, 101679 .

Haywood, V. B. (2000). Current status of nightguard vital bleaching. Compend Contin Educ Dent Suppl, (28), 10-48.

Kury, M., Wada, E. E., Silva, D. P. D., Tabchoury, C. P. M., Giannini, M., \& Cavalli, V. (2020). Effect of violet LED light on in-office bleaching protocols: a randomized controlled clinical trial. J Appl Oral Sci. 28, 20190720.

Lima, F. V., Mendes, C., Zanetti-Ramos, B. G., Nandi, J. K., Cardoso, S. G., Bernardon, J. K. et al. (2019). Carbamide peroxide nanoparticles for dental whitening application: Characterization, stability and in vivo/in situ evaluation. Colloids Surf B Biointerfaces, 179, $326-333$.

Liu, H., Huang, M., Cui, G., Luo, M. R., \& Melgosa, M. (2013). Color-difference evaluation for digital images using a categorical judgment method. J Opt Soc Am A Opt Image Sci Vis, 30(4), 616-26.

Loretto, S.C., Libdy, M. R., Ribeiro F.S.R., Braga, E. M. F., Carneiro, K. G.K. \& Silva e Souza Júnior, M.H. (2013). Influence of whitening gel on pulp chamber temperature rise by in-office bleaching technique. Rev Odontol UNESP, 42(6), 432-438.

Luque-Martinez, I., Reis, A., Schroeder, M., Muñoz, M.A., Loguercio, A.D., Masterson, D., et al. (2016) Comparison of efficacy of tray-delivered carbamide and hydrogen peroxide for athome bleaching: a systematic review and meta-analysis. Clin Oral Investig, 20(7), 1419-33.

Maran, B. M., Burey, A., de Paris Matos, T., Loguercio, A. D., Reis, A. (2018) In-office dental bleaching with light vs. without light: A systematic review and meta-analysis. J Dent, 70, 1-13.

Maran, B. M., Ziegelmann, P. K., Burey, A., de Paris Matos, T., Loguercio, A. D., \& Reis, A. (2019). Different light-activation systems associated with dental bleaching: a systematic review and a network meta-analysis. Clin Oral Investig, 23(4), 1499-1512.

Michaelis. (1998). Moderno dicionário da língua portuguesa. São Paulo: Melhoramentos.

Ontiveros, J. C., Paravina, R. D. (2009). Color change of vital teeth exposed to bleaching performed with and without supplementary light. J Dent. 37 (11), $840-847$.

Ontiveros, J. C. (2011). In-office vital bleaching with adjunct light. Dent Clin North Am, 55(2), 241-253.

Ray, D. S. (2014). Using light to enhance in-office vital bleaching may increase both efficacy and tooth sensitivity. J Am Dent Assoc, 145(11), 1159-1160.

Sharma, G., Wu, W. C., \& Daa, E. N. (2005). The CIEDE2000 color-difference formula: Implementation notes, supplementary test data, and mathematical observations. Color Res Appl, 30(1), 21-30.

Sulieman, M. (2004). An overview of bleaching techniques: I. History, chemistry, safety and legal aspects. Dent Update. 31(10), 608-610.

Viscio, D., Gaffar, A., Fakhry-Smith, S., \& Xu, T. (2000). Present and future technologies of tooth whitening. Compend Contin Educ Dent Suppl. (28), 36-49.

Zach L, \& Cohen G (1965) Pulp response to externally applied heat Oral Surgery, Oral Medicine and Oral Pathol 19(4) 515-530.

Nakonieczna-Rudnicka, M., Bachanek, T., Madejczyki, M., Grajewskai, I., \& Kobyłecka, E. (2015). Teeth whitening versus the influence of extrinsic factors on teeth stains. Przegl Lek, 72(3), 126-130.

Torres, C. R., Zanatta, R. F., Godoy, M. M., \& Borges AB. (2021). Influence of Bleaching Gel Peroxide Concentration on Color and Penetration through the Tooth Structure. J Contemp Dent Pract. 22(5), 479-483. 